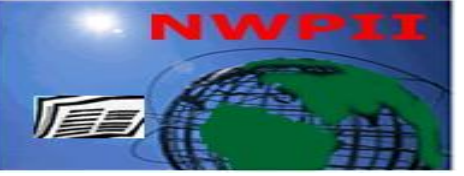

American Journal of Biomedical Sciences

ISSN: 1937-9080

nwpii.com/ajbms

\title{
Experimental Non-obstructive Chronic Renal Infection Model with Planktonic and Biofilm Cells of Pseudomonas Aeruginosa
}

\author{
Rahul Mittal $^{1,2^{*}}$, Amanpreet Kaur ${ }^{1}$, Kusum Joshi ${ }^{3}$, Ritambra Nada ${ }^{3}$, Sanjay Chhibber ${ }^{1}$, \\ Kusum Harjai ${ }^{1}$, Saroj Sharma ${ }^{1}$
}

${ }^{1}$ Department of Microbiology, Panjab University, Chandigarh, INDIA.

${ }^{2}$ Division of Infectious Diseases, Childrens Hospital Los Angeles, Los Angeles, California, USA

${ }^{3}$ Department of Pathology, PGIMER, Chandigarh, INDIA.

*Corresponding Author

Dr Rahul Mittal

Division of Infectious Diseases, MS\#51

Childrens Hospital Los Angeles,

4650 Sunset Boulevard

Los Angeles, CA, 90027, USA

Telephone: 323-361-5809

E-Mail: ramittal@chla.usc.edu; rahul_mittal20022@yahoo.com

Received: 30 November 2008; $\mid$ Revised: 9 January 2009; $\mid$ Accepted: 25 January 2009

\begin{abstract}
Availability of an acceptable animal model, which closely mimics human clinical situations in terms of receptors and route of entry, is of utmost importance to study host parasite interaction. In the present study, Swiss Webster (LACA) strain of female mice was chosen for induction of chronic renal inflammation by planktonic as well as biofilm cells of Pseudomonas aeruginosa. Bacterial inoculum was instilled thrice intrauretherally with the help of catheter. Both the cell forms were able to induce chronic renal inflammation in the experimental animals. However, severity of lesions induced by four day old biofilm cells was more as compared to planktonic cells. The chronic pyelonephritis model holds great promise for understanding the biology and pathogenesis of $P$. aeruginosa induced urinary tract infections as well as in development of effective preventive strategies.
\end{abstract}

Keywords: Pseudomonas aeruginosa; Planktonic cells; Biofilm cells; Chronic renal infection; UTI mouse model.

\section{Introduction}

Pseudomonas aeruginosa is an opportunistic pathogen of humans. It is the most common pathogen associated with hospital acquired urinary tract infections [1]. Urinary tract infections (UTIs) caused by $P$. aeruginosa occur as complication of long term indwelling catheterization, surgery or 
instrumentation [2, 3]. Urinary catheter represents the initial site of bacterial attachment and proliferation in such patients. $P$. aeruginosa growing in the form of biofilms on these catheters are source of ascent of bacteria into the urinary tract, leading to acute as well as chronic infections [4].

Existing information regarding the pyelonephritic potential of $P$. aeruginosa is mostly based on epidemiological studies [5]. This approach, however, can only identify association between certain serogroups, bacterial virulence traits and their role in pathogenicity. To understand the pathogenesis of the disease, availability of an acceptable animal model is the foremost requirement which preferably should involve minimal or no manipulation of the urinary tract [6]. Choice of animal species is also of critical importance since it should allow establishment of infection with human clinical isolates. Experimental pyelonephritis is relatively easy to establish in rats because of spontaneous vesicouretric reflux (VUR) [6]. However, rat uroepithelial cells do not match human cells in the expression of receptors for P-fimbriae of Escherichia coli [7]. At the receptor level, the globoside isolated from the rat kidney contain a Gal $\alpha$ (1-3) Gal $\beta$ linkage instead of the critical Gal $\alpha(1-4)$ Gal $\beta$ linkage present in humans [8]. In contrast, mouse renal tissue has been found to contain an appreciable concentration of Gal $\alpha$ (14) Gal $\beta$ containing glycolipid which matches with that of humans [8]. Further, it has been recognized that Tamm-Horsfall glycoprotein (THP) present in mouse urine is physically, chemically and immunologically almost identical to THP found in human urine [9]. In earlier studies from our laboratory, rodents have been found to be suitable for inducing acute pyelonephritis with E. coli [1012]. In literature, a rat model has been reported for induction of chronic pyelonephritis by $P$. aeruginosa, but it involves placement of foreign body into the bladder [13]. In addition, marked genetic similarity between mice and humans has been recognized [14] and therefore, mouse will be more desirable animal for establishing experimental UTI. It is for this reason that in the present study, a model for chronic pyelonephritis has been induced by $P$. aeruginosa in Swiss
Webster (LACA) mice employing ascending route of infection.

\section{METHODS}

Bacterial strains. A urinary isolate of Pseudomonas aeruginosa, PA5, employed in earlier studies [15, 16], isolated from hospitalized patient having complicated urinary tract infection and serotyped as $\mathrm{O} 11$ by Laboratory of HealthCare Associated Infection, London was used. This strain produced most of the recognized virulence factors such as alginate, phopholipase $\mathrm{C}$, protease, elastase, pyochelin, pyoverdin and hemolysin. In addition, a standard strain of Pseudomonas aeruginosa, PAO, producing most of the above mentioned virulence factors, was obtained from Barbara H. Iglewski, University of Rochester, New York (U.S.A.). Both the strains were grown overnight in nutrient broth at $37^{\circ} \mathrm{C}$ under shaking conditions and harvested by centrifugation. Cells were washed three times with phosphate-buffered saline (PBS), resuspended to a concentration of $1 \times 10^{8}$ organisms per $\mathrm{ml}$ in PBS and was used as planktonic cells for giving infection in mice.

\section{Generation of biofilm cells}

Original method of Ladd et al. [17] as standardized in our laboratory [15] was followed for generation of biofilms. Foley's catheter (Bardia) was cut into $1.0 \mathrm{~cm}$ pieces and put into nutrient broth flasks. These were inoculated with $100 \mu \mathrm{l}$ of overnight culture and incubated at $37^{\circ} \mathrm{C}$. After every $24 \mathrm{~h}$ catheter pieces were removed from each flask, rinsed three times with phosphate buffer saline (PBS) and transferred to the new flask containing nutrient broth till day 4. On day 4, catheter pieces were rinsed three times with PBS to remove adherent bacteria and sliced longitudinally into equal halves. Cells were removed from the surface of catheter pieces by scrapping the inner surface with sterile scalpel blade. Dispersed sample was then centrifuged and the biofilm cells were suspended in $1 \mathrm{ml}$ PBS. Bacterial concentration was confirmed by viable counts [15]. 


\section{Animals}

Female LACA (Swiss Webster) mice, weighing 20-30 g, obtained from Central Animal House, Panjab University, Chandigarh, were used for the study. They were fed on standard antibiotic free synthetic feed. Mice without bacteriuria (confirmed by culture) were selected for the study.

\section{Induction of chronic pyelonephritis}

Bacterial inoculum was introduced by the method of Mittal et al. [15]. The dose for $P$. aeruginosa (both cell forms) was $10^{8} \mathrm{CFU} / \mathrm{ml}$ as employed earlier [16]. A soft intramedic non radiopaque polyethylene tubing with an outer diameter of $0.61 \mathrm{~mm}$ (Clay Adams, USA) was inserted into the urethral meatus and advanced into the bladder. $0.05 \mathrm{ml}$ of inoculum containing $10^{8} \mathrm{CFU} / \mathrm{ml}$ was instilled slowly into the bladder to avoid leakage and reflux, kept in place for 10 min and then withdrawn slowly. To achieve persistent infection, these animals were reinfected 15 days after the first infection followed by third infection after 16 weeks of initial dose. In all, organisms were introduced three times via urethera [18]. Experimental animals were sacrificed at 1, 3, 5, 7, 10, 12, 15, 17, 20, 24, 30, $60,90,120$ and 150 postinfection days. All the animal experiments were carried out in triplicate in two sets and each group consisted of six mice (total 36 mice). The study protocol was approved by the institutional ethics committee for animal experimentation.

\section{Assessment of neutrophil response}

Tissue neutrophils were quantitated using myeloperoxidase (MPO) assay [15]. Kidneys were homogenized in $2 \mathrm{ml}$ of $50 \mathrm{mM}$ potassium phosphate, $\mathrm{pH} 6.0$ with $5 \%$ hexadecyltrimethylammonium bromide and $5 \mathrm{mM}$ EDTA. Homogenates were sonicated and centrifuged. Supernatants were mixed in the ratio of 1:15 with assay buffer and read at $490 \mathrm{~nm}$. MPO units were calculated as change in absorbance over time. All the experiments were carried in triplicate in two sets.

\section{Malondialdehyde (MDA) estimation}

MDA was estimated following method of Wills [19]. Briefly $0.5 \mathrm{ml}$ of tissue supernatant was added to $0.5 \mathrm{ml}$ of Tris $\mathrm{HCl}(0.1 \mathrm{M}, \mathrm{pH} 7.4)$ and incubated at $37^{\circ} \mathrm{C}$ for $2 \mathrm{~h} .1 \mathrm{ml}$ of trichloroacetic acid was then added and centrifuged at $700 \mathrm{~g}$ for $10 \mathrm{~min} .1 \mathrm{ml}$ supernatant was mixed with equal volume of thiobarbituric acid $(0.67 \% \mathrm{w} / \mathrm{v})$ and kept in boiling water bath for $10 \mathrm{~min}$. After cooling volume was made to 3 $\mathrm{ml}$ with double distilled water and absorbance was taken at $532 \mathrm{~nm}$. Amount of MDA formed was expressed in nanomoles per milligram protein ( $\mathrm{n}$ moles/mg).

\section{Measurement of IgG responses}

$\mathrm{IgG}$ responses was measured in renal tissue homogenates using ELISA kit ( $\mathrm{R} \&$ D Systems, Minneapolis). Kidneys were homogenized in $3 \mathrm{ml}$ of lysis buffer containing $0.5 \%$ Triton X-100, 150 $\mathrm{mM} \mathrm{NaCl}, 15 \mathrm{mM}$ Tris, $1 \mathrm{mM} \mathrm{CaCl}_{2}$ and $1 \mathrm{mM}$ $\mathrm{MgCl}_{2}$, pH 7.4, using a tissue homogenizer. Homogenates were incubated on ice for $30 \mathrm{~min}$, then centrifuged at $1500 \mathrm{x} \mathrm{g}$ for $10 \mathrm{~min}$, supernatants were collected and passed through a $0.45 \mathrm{~mm}$ filter and used for ELISA. ELISA was carried out according to manufacturer's guideline.

\section{Assessment of renal bacterial load}

One half of both the kidneys were removed aseptically, weighed and homogenized in $1 \mathrm{ml}$ of sterile PBS. Quantitative bacterial counts per gram of the kidney tissue were calculated as reported by Harjai et al. [16].

\section{Assessment of renal pathology}

Kidney tissues preserved in formalin, were dehydrated in an ethanol gradient of 30-100\%. Tissues were then embedded in wax, sectioned and stained with haemotoxylin and eosin [16]. Medulla, cortex, calyx and subcalyx of each kidney were evaluated on semiquantitative scale of 0 to $4[12,16]$. These individual scores were then added to obtain overall severity score, which ranged from 0 to 16 . The histopathological examination was done by a pathologist experienced in urinary tract pathology.

\section{Statistical Analysis}

Results were statistically analyzed by applying Student's $t$ test and Fischer test for 
calculating $P$ values. $P<0.05$ were considered statistically significant.

\section{Results}

In the present study an attempt was made to establish chronic renal infection in mice with planktonic and biofilm cell forms of $P$. aeruginosa. Bacteria were demonstrable in the kidneys of mice infected with planktonic cells till $12^{\text {th }}$ postinfection day whereas biofilm cells persisted for 15 days in renal tissue of mice following first dose of the inoculum. At this time period, renal bacterial counts were found to be significantly higher $(P<0.001)$ in animals inoculated with biofilm cells of $P$. aeruginosa as compared to the planktonic cells (Fig. 1). Following instillation of second dose (at $15^{\text {th }}$ postinfection day) and third dose (at $120^{\text {th }}$ postinfection day), the kidneys of animals were found to be sterile with both cell forms when checked at $150^{\text {th }}$ postinfection day (Fig. 1).

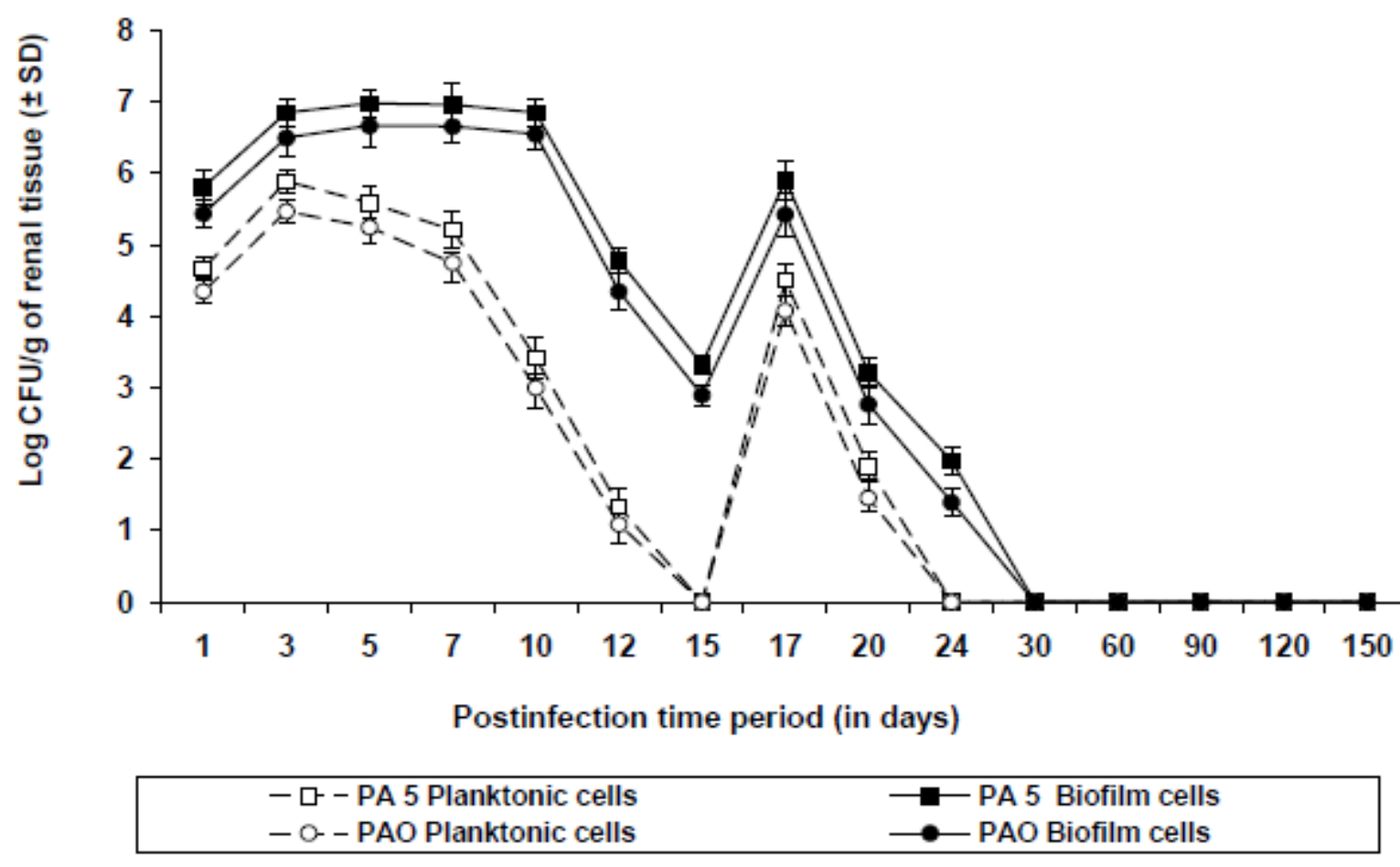

Fig. 1. Comparative renal bacterial counts of planktonic and biofilm cells of $P$. aeruginosa at different postinfection time intervals. The data represents mean \pm SD values and is representative of two independent experiments carried out in triplicate. $P<0.001$ planktonic vs biofilms cells.

Myeloperoxidase estimation was used as an index of neutrophil recruitment in the present study. It was observed that after first dose neutrophil recruitment started and reached significant level in kidney in response to infection showing peak at $3^{\text {rd }}$ and $5^{\text {th }}$ postinfection day in case of planktonic and biofilm cells respectively (Fig. 2). When animals were infected with second dose significant increase in neutrophil influx was observed which persisted till $120^{\text {th }}$ postinfection day. When animals were infected third time, again significant increase in neutrophil recruitment was observable with both planktonic and biofilm cells (Fig. 2). However biofilm cells were significantly more potent stimulators of neutrophil recruitment as compared to planktonic cells $(P<0.001)$.

Production of MDA was used as marker of tissue damage in this study. It was observed that there was persistent MDA production in renal tissue of mice infected with $P$. aeruginosa (Fig. $3)$. MDA production was more with biofilm cells in comparison to planktonic cells $(P<0.001)$ indicating that biofilm cells cause more tissue damage. 


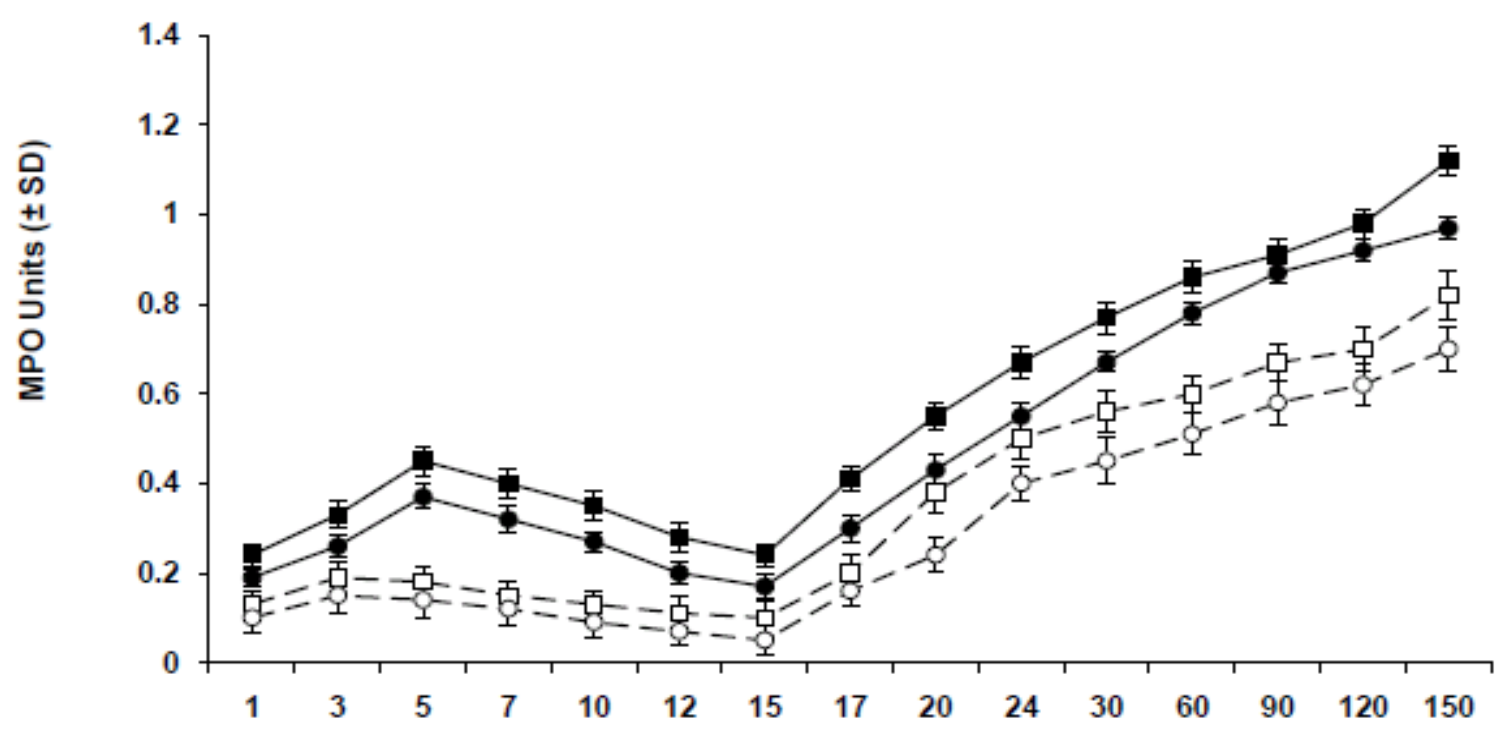

Postinfection time period (in days)

\begin{tabular}{|ll|}
\hline$-\square-$ PA 5 Planktonic cells & - PA 5 Biofilm cells \\
- - PAO Planktonic cells & - PAO Biofilm cells \\
\hline
\end{tabular}

Fig. 2. MPO activity in renal tissue of mice infected with planktonic and biofilm cells of P. aeruginosa at different postinfection time intervals. The data represents mean \pm SD values and is representative of four independent experiments carried out in triplicate. $P<0.001$ planktonic vs biofilms cells.

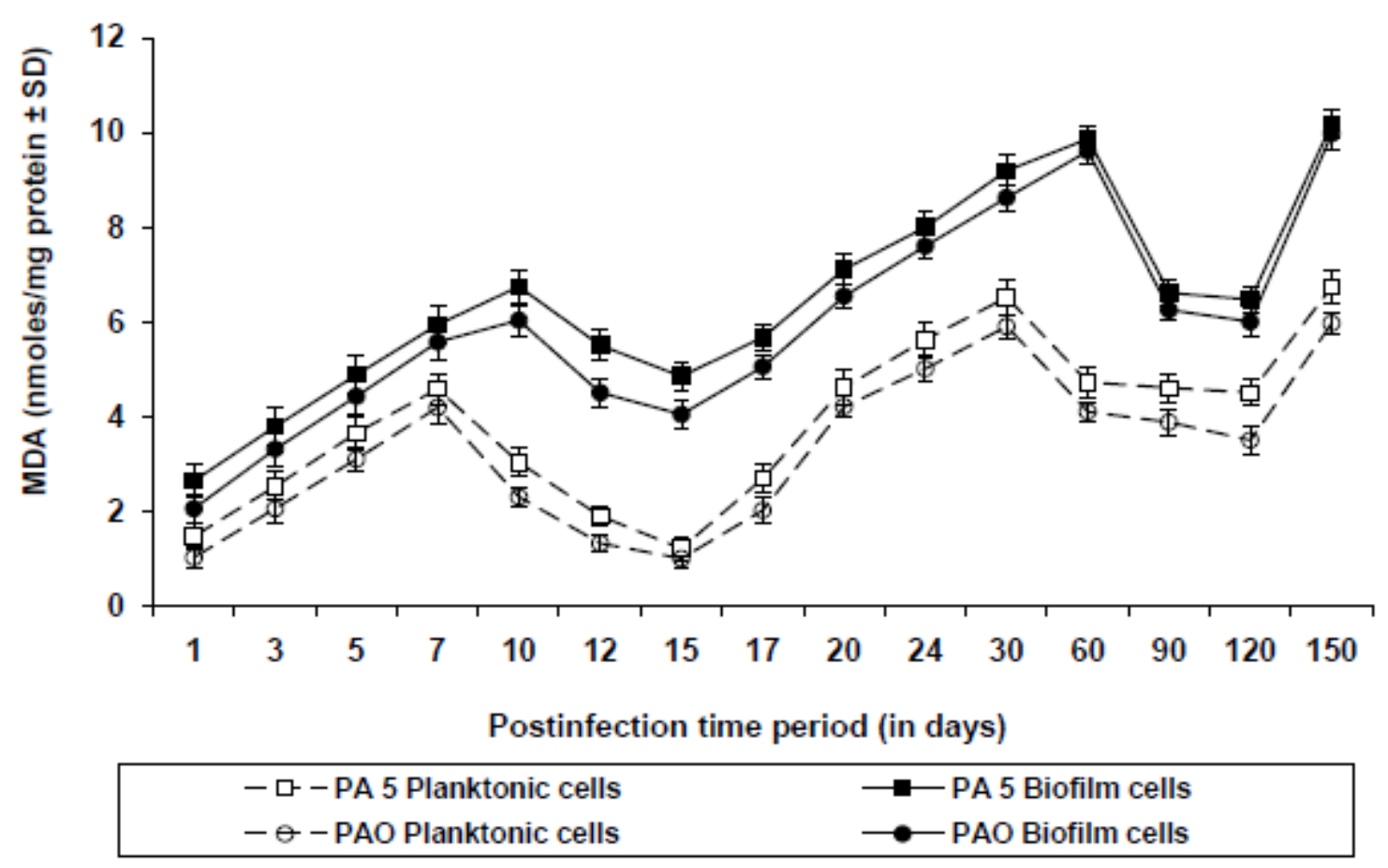

Fig. 3. MDA production in renal tissue of mice infected with planktonic and biofilm cells of $P$. aeruginosa at different postinfection time intervals. The data represents mean \pm SD values and is representative of five independent experiments carried out in triplicate. $P<0.001$ planktonic vs biofilms cells. 
In the present investigation, IgG production in renal tissue of mice was measured using ELISA. After instillation of first dose, IgG production increased with increase in postinfection time period showing peak at $7^{\text {th }}$ postinfection day in case of planktonic cells and at $10^{\text {th }}$ postinfection day in case of biofilm cells (Fig. 4). Significant increase in $\mathrm{IgG}$ levels was observed following instillation of second dose which persisted till $120^{\text {th }}$ day. When third dose was administered rise in $\mathrm{IgG}$ levels was again observed in animals sacrificed on $150^{\text {th }}$ postinfection day. Biofilm cells produced significantly higher levels of $\mathrm{IgG}$ at all time intervals as compared to their planktonic counterparts $(P<0.001)$.

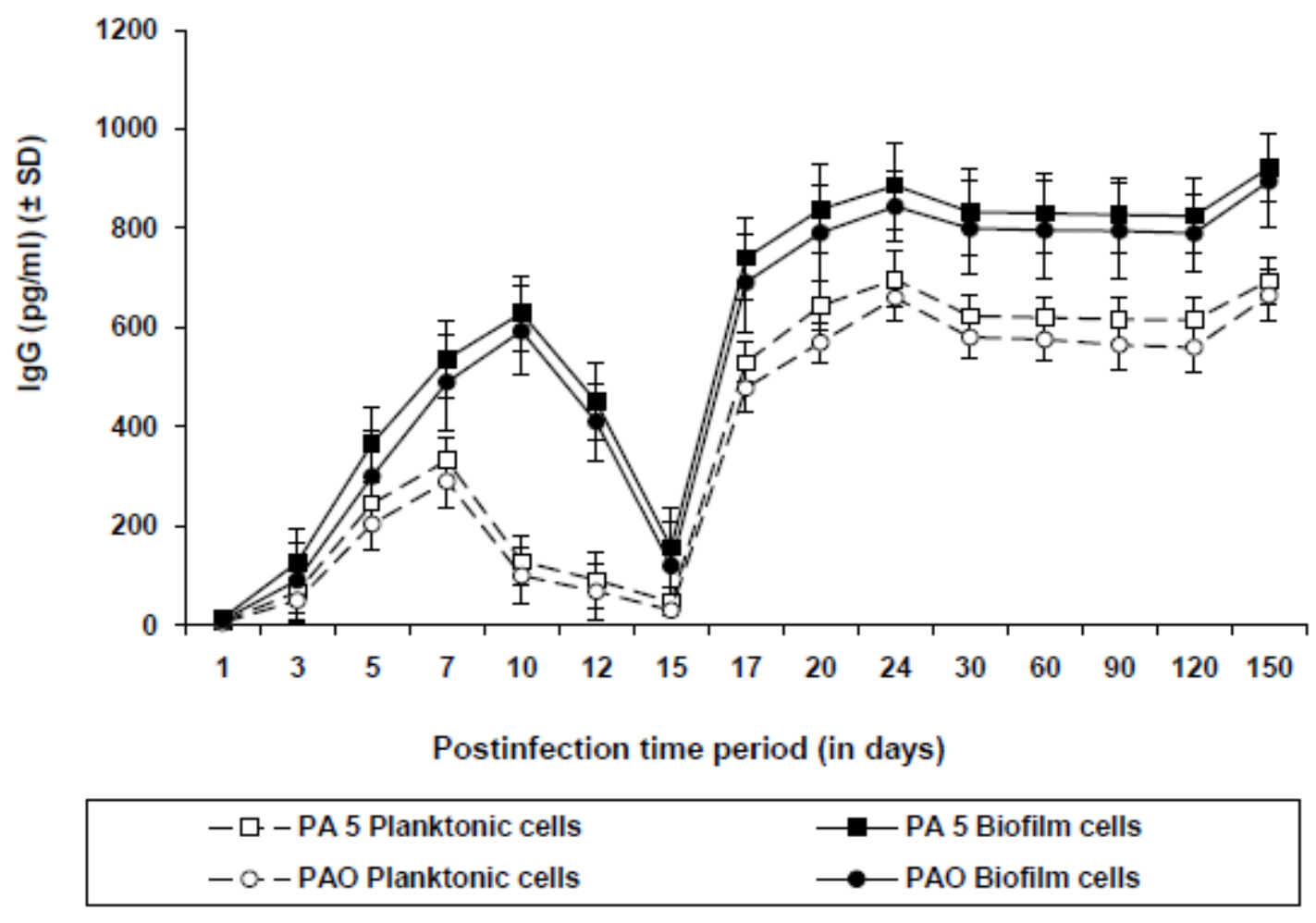

Fig. 4. IgG production in renal tissue of mice infected with planktonic and biofilm cells of P. aeruginosa at different postinfection time intervals. The data represents mean \pm SD values and is representative of four independent experiments carried out in triplicate. $P<0.001$ planktonic vs biofilms cells.

Pathological evaluation of renal tissue revealed that renal lesions were significantly more with four day old biofilm cells as compared with planktonic cells $(P<0.001)$ at all time intervals based on the severity scores (Fig. 5). Acute inflammatory changes characterized by infiltration of polymorphonuclear leucocytes in the interstitium were observed upto 15 postinfection day. Mild cortical inflammation and moderate degree of chronic inflammation in the cortex was observed at $30^{\text {th }}$ postinfection day (Fig. 6A). After $60^{\text {th }}$ postinfection day, cortical regions showed severe inflammation and were infiltrated with large number of lymphocytes with marked destruction of tubules (Fig. 6B). Medulla, also showed multiple foci of chronic inflammation along with presence of hyaline casts which changed to periglomerular fibrosis (Fig. 6C) after $120^{\text {th }}$ post infection day. Medullary degeneration along with severe inflammation was observable at $150^{\text {th }}$ postinfection day (Fig. 6D). Ulceration of the calyceal lining with dense chronic inflammation in the subcalyceal region was also observable (Fig. 6E). Mononuclear cell infiltration and fibrosis was more in renal tissue of mice infected with biofilm cells in comparison to experimental animals infected with planktonic cells. 
A

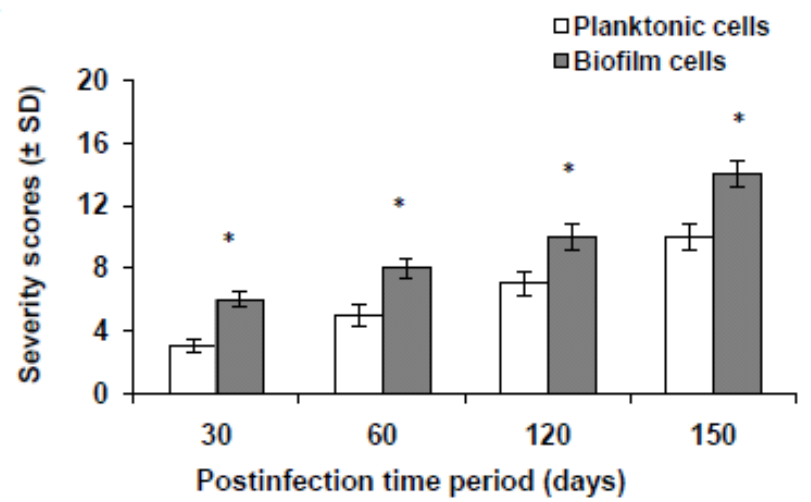

B

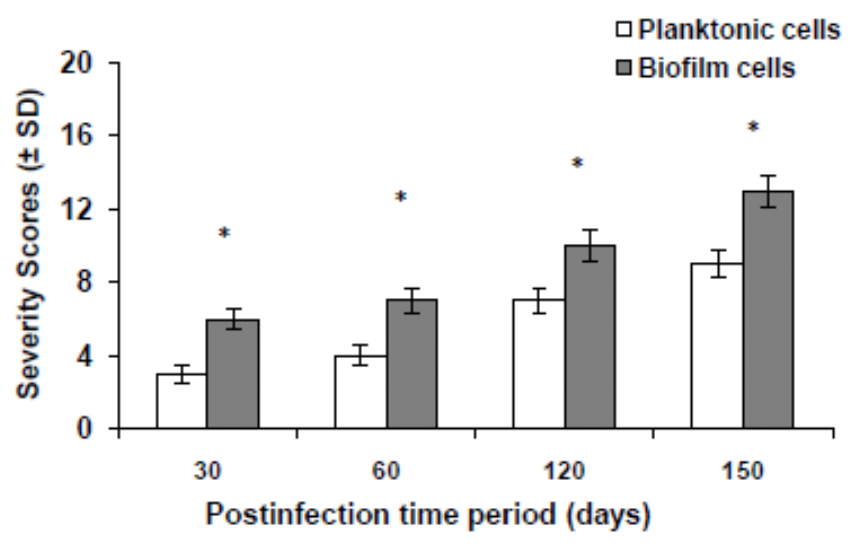

Fig. 5. Comparative renal severity scores of planktonic and biofilm cells of $P$. aeruginosa uroisolate (PA5) (A) and standard strain (PAO) (B). The data represents mean $\pm \mathrm{SD}$ values. $* P<0.001$ planktonic vs biofilms cells.

\section{Discussion}

In this study we report a model for chronic ascending pyelonephritis in female Swiss Webster (LACA) mice following transuretheral introduction of planktonic and biofilm cells of $P$. aeruginosa, without obstruction or presence of indwelling catheter. $P$. aeruginosa is an epitome of opportunistic pathogen [20]. This pathogen has a tendency to form microcolonies on surface of indwelling catheters which coalesce together to form biofilms [21]. Biofilms are more resistant to innate host defense mechanisms as well as to antimicrobial agents in comparison to their planktonic counterparts [22]. This leads to difficulty in their eradication which can cause persistent infections and therefore is a major concern for clinicians. In the present study we observed that both planktonic and biofilm cells of $P$. aeruginosa were not able to persist in mouse renal tissue even after repeated instillations when checked on $150^{\text {th }}$ postinfection day. However neutrophil recruitment, MDA formation, IgG production, and severity of renal lesions was significantly more with biofilm cells as compared to their planktonic counterparts $(p<0.001)$. On $12^{\text {th }}$ postinfection day, both cell forms of the infecting organism were demonstrable in the renal homogenate but four weeks after infection, kidneys were found to be sterile with both planktonic as well as biofilm cell forms of $P$. aeruginosa. Gupta et al. [18] established chronic renal infection with matching dose of uropathogenic E. coli. They also found kidneys to be sterile at $16^{\text {th }}$ week post infection period. In case of $E$. coli it has been reported that type I fimbriae and P-fimbriae play significant role in induction of infection [23]. In $P$. aeruginosa lectins namely PAI-L and PAII-L have been reported which resemble P-fimbriae and type I fimbriae of $E$. coli respectively in terms of both sugar specificity and binding to human $\mathrm{P}$ blood group system antigens [24]. However, their role in establishment of infection induced by $P$. aeruginosa still remains to be elucidated.

In one available report of foreign body associated chronic UTI in rats induced with $P$. aeruginosa, Kurosaka et al. [13] used a spiral polyethylene tubing (PT) which was placed transurethrally into the bladder. This was followed by inoculation with planktonic cells of $P$. aeruginosa. Persistence of organisms in the kidneys and bladder was significantly enhanced due to development of thick biofilm on the surface of PT suggesting continuous introduction of bacteria from the biofilm adhering to the PT through ascending route. Kidneys were shown to have chronic renal inflammation which was continuous and sporadic in the pelvis as well as in adjacent tissues. However, this model involves placement of foreign body into the bladder which is likely to disrupt the mucopolysaccharide coating, interfering with natural resistance to infection. In comparison, an unmanipulated 
chronic model of pyelonephritis was employed in the present study. Further the experimental animals were observed only for 14 days by these workers thus missing the evolution of true form of chronic pyelonephritis. The observation period of the present study, however, was $150^{\text {th }}$ postinfection day, time at which renal scarring was

A

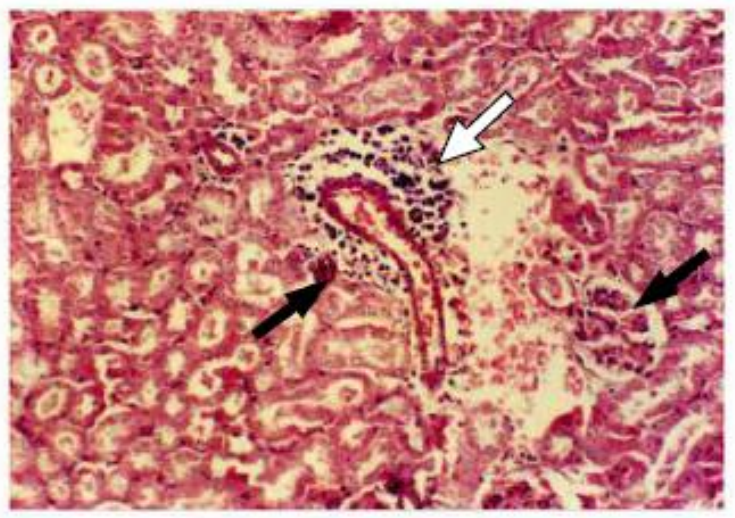

C

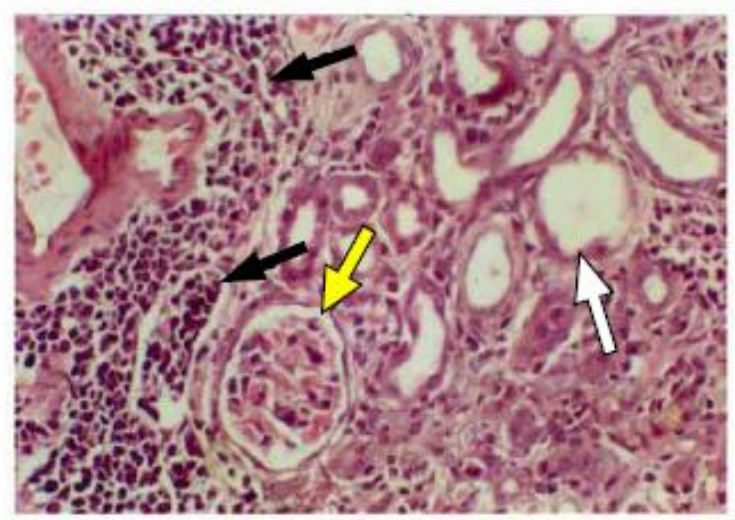

also observable, hence offering distinct advantage. Chronic UTI model reported in the present study, hence, is simple and relevant which can be further employed for studying pathogenesis of chronic form of renal infection caused by $P$. aeruginosa without placement of any foreign body.

\section{B}

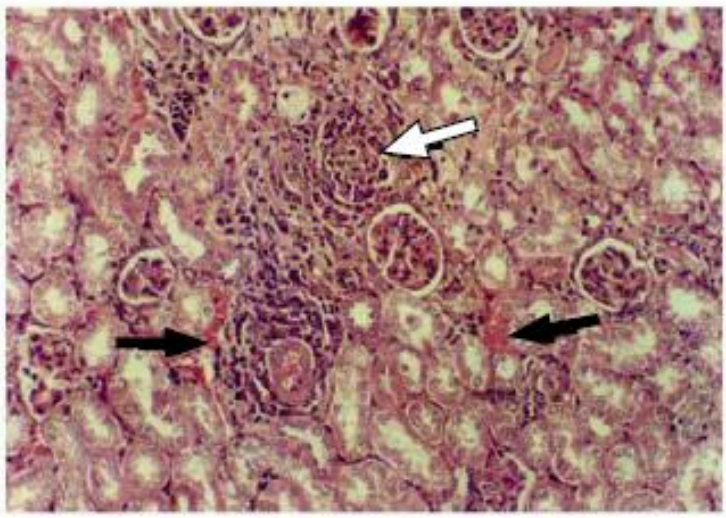

D

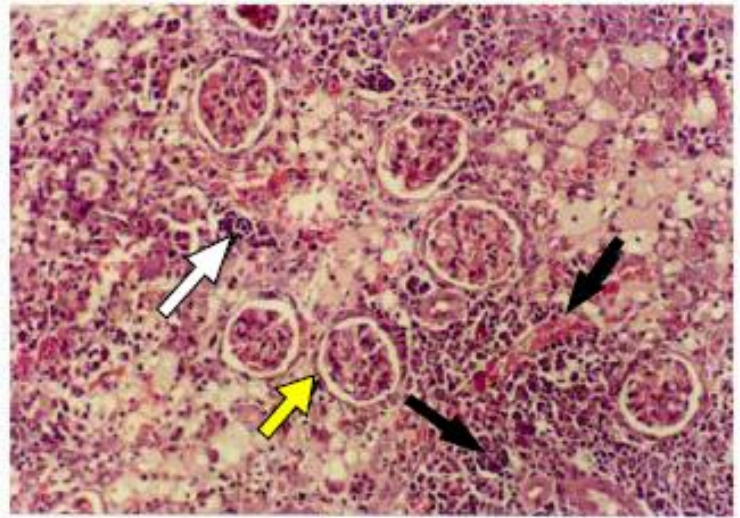

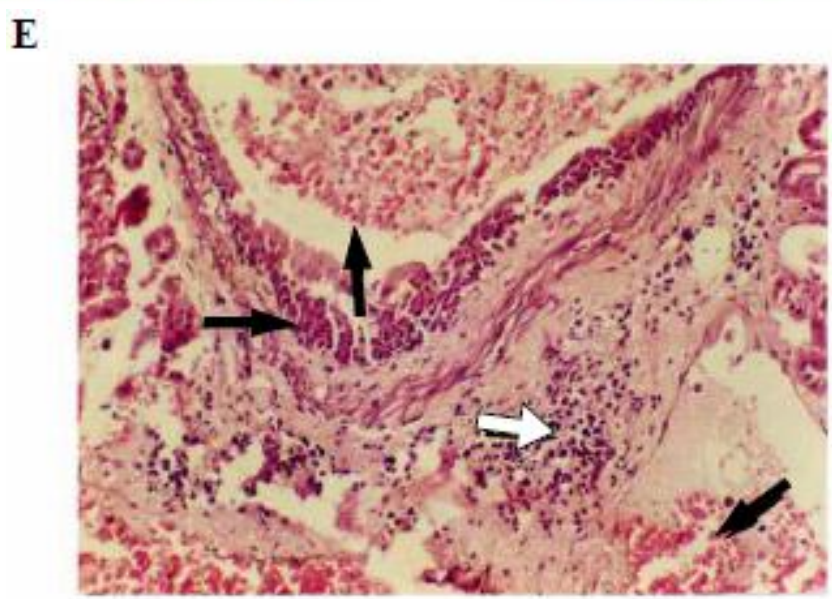

Fig. 6. Histopathological examination of renal tissue infected with $\boldsymbol{P}$. aeruginosa. Renal and bladder tissue of mice were sectioned and stained with H\&E. Photograph showing mild cortical inflammation (black arrows) and moderate degree of chronic inflammation (white arrow) in the cortex (A) (H\&E X 140). 
Photomicrograph showing severe degree of chronic inflammatory cell infiltration (white arrow) in the cortex along with destruction of tubules (black arrows) (B) (H\&E X 140). Photomicrograph showing dense chronic inflammation in the cortex (black arrows), along with mild interstitial fibrosis (yellow arrow) and tubular dilation (white arrow) (C) (H\&E X 280). Photomicrograph showing periglomerular fibrosis (yellow arrow), interstitial chronic inflammation (white arrow) and degenerative changes in tubules (black arrows) (D) $(\mathrm{H} \& \mathrm{E} X \mathrm{X}$ 140). Photomicrograph showing ulceration of the calyceal lining with dense chronic inflammation (black arrows) in the subcalyceal region (white arrow) (E) (H\&E X 280).

Phagocytic cells form first line of defense against pathogens, especially at mucosal surfaces. Neutrophils and monocytes from blood migrate to the site of infection and help in combating infection. However excessive recruitment of phagocytic cells can cause tissue damage and can be detrimental for the host. In the present study, persistent neutrophil recruitment into renal tissue of mice assessed by myeloperoxidase assay was observed following administration of bacterial inoculum. Angell et al. [25] also reported that there could be significant inflammatory response even in the absence of organisms indicating persistence of bacterial antigens. In addition, reactive oxygen species which are generated following infection can lead to oxidation of lipid membranes and tissue damage. MDA is one of the most stable products of lipid peroxidation and has been used as indicator of tissue damage by many workers. In the present study, persistent production of MDA following repeated instillation of $P$. aeruginosa could have contributed to the tissue damage. Rise in MDA levels has been correlated with ischemia, chronic renal failure and tubulointerstitial injury [26]. Recently it has been proposed that cellular components from necrotic neutrophils can serve as a biological matrix to facilitate $P$. aeruginosa biofilm formation indicating that this pathogen can utilize host innate defense mechanisms for its own survival [27].

Guze et al. [28] explained that absence of organisms could be result of production of high level of opsonizing antibodies against E. coli which could have helped in clearance of organisms. In the present study, we also observed persistent production of IgG antibodies in renal tissue of experimental animals against $P$. aeruginosa which could have helped in clearance of organisms. Paucity of literature in relation to $P$. aeruginosa induced chronic UTI is a limiting factor for making comparisons. However correlation between antibody responses and poor prognosis in cystic fibrosis patients infected with $P$. aeruginosa has been attributed to immune complex induced chronic inflammation but due to underlying disease, the organisms persisted in lung parenchyma [29]. Further, it has also been shown that complement activation and generation of high level of proinflammatory cytokines like TNF- $\alpha$, IL-1, IL-6 and IL-8 in lungs can also play a contributory role [29]. In relation to UTI to what extent persistence of bacterial antigens, formation of immune complexes and triggering of cytokine network by $P$. aeruginosa affect the course of infection, needs to be addressed to in future studies. The enhanced virulence of biofilm cells compared to planktonic cells observed in this study may be attributed to increased adhesive ability to uroepithelial cells as well as resistance to killing by phagocytes as reported in earlier studies from our laboratory and by other workers [30, 31]. It is known that during transition of $P$. aeruginosa from planktonic, free-living organisms to attached, matrix enclosed communities with threedimensional structure (biofilms), they are inherently less susceptible to the innate and adaptive killing components of the host [32-35]. Moreover, $P$. aeruginosa biofilms appear to be resistant to toxic oxygen products such as $\mathrm{H}_{2} \mathrm{O}_{2}$, easily converting it back to $\mathrm{O}_{2}$ with powerful catalase and superoxide dismutase activities [3638]. In this context, the proposed model will be of great relevance to study the pathogenesis of infections caused by $P$. aeruginosa in the normal urinary tract in planktonic and biofilm cell modes. In addition, a comparison can also be made between clinical and environmental isolates of $P$. aeruginosa since it has been reported by Alonso et $a l$. [39] that clinical and non-clinical strains of $P$. aeruginosa might be functionally equivalent. It also remains to be seen as to how effectively other 
uroisolates establish in the experimental model being reported here.

\section{Acknowledgements}

We are thankful to Judith Glover Laboratory of HealthCare Associated Infection, London for serotyping of Pseudomonas aeruginosa and Dr. Barbara H. Iglewski, (University of Rochester, Rochester, New York, USA) for providing us standard strain of $P$. aeruginosa.

\section{References}

1. Ronald, A. The etiology of urinary tract infection: traditional and emerging pathogens. Dis Mon, 2003, 49, 71-82.

2. Williams, D.H.; Schaeffer, A.J. Current concepts in urinary tract infections. Minerva Urol Nefrol, 2004, 56, 15-21.

3. Driscoll, J.A.; Brody, S.L.; Kollef, M.H. The epidemiology, pathogenesis and treatment of Pseudomonas aeruginosa infections. Drug, 2007, 67, 351-358.

4. Hoiby, N.; Johansen, H.K.; Moser, C.; Sang, Z.; Ciofu, O.; Kharazmi, A. Pseudomonas aeruginosa and the in vitro and in vivo biofilm mode of growth. Microbe Infect, 2001, 3, 2335.

5. Visca, P.; Chiarini, F.; Mansi, A.; Vetriani, C.; Serino, L.; Orsi, N. Virulence determinants in Pseudomonas aeruginosa strains from urinary tract infections. Epidemiol Infec, 1992, 108, 323-336.

6. Kaijser, B.; Larsson, P. Experimental acute pyelonephritis caused by enterobacteria in animals. A Review. J Urol, 1982, 127, 786790.

7. Korhonen, T.K.; Leffler, H.; Svanborg, E.C. Binding specificity of piliated strains of Escherichia coli and Salmonella typhimurium to epithelial cells, Saccharomyces cervisiae cells and erythrocytes. Infect Immun, 1981, 32, 796-804.

8. Lyrela, T.A.; Gross, S.K.; McCluer, R.H. Glycosphingolipid patterns in primary mouse kidney cultures. J Cell Physiol, 1986, 129, 390-394.

9. Pak, Y.; Zhang, Z.T.; Hasty, D.L.; Wu, X.R.
Tamm-Horsfall protein binds to type I fimbriated Escherichia coli and prevents $E$. coli from binding to uroplankin Ia and $\mathrm{Ib}$ receptors. J Bio Chem, 2001, 276, 9924-9930.

10. Sharma, S.; Harjai, K.; Mittal, R. Enhanced siderophore production and mouse kidney pathogenicity by urine grown Escherichia coli. J Med Microbiol, 1991, 35, 325-329.

11. Harjai, K.; Chhibber, S.; Rao Bhau, L.N.; Sharma, S. Introduction of plasmid carrying an incomplete set of genes of aerobactin production confers virulence characteristic to Escherichia coli HB101. Microb Pathog, 1994, 17, 261-270.

12. Garg, U.C.; Ganguly, N.K.; Sharma, S.; Chakravati, R.N.; Bhatnagar, R.K. Quantitative histopathological method for evaluation of experimental ascending pyelonephritis. Med Sci Res, 1987, 15, 367368.

13. Kurosaka, Y.; Ishida, E.; Yamamura, H.; Takase, T.; Otani, H.; Kumon, A. A non surgical rat model of foreign body associated urinary tract infection with Pseudomonas aeruginosa to plastic catheters. Microbiol Immunnol, 2001, 45, 9-15.

14. Kondo, S.; Shinagawa, A.; Saito, T.; Kiyosawa, H.; Yamanaka, I.; Aizawa, K.; Fukuda, S.; Hara, A.; Itoh, M.; Kawai, J.; Shibata, K.; Hayashizaki, Y. Computational analysis of full length mouse cDNAs compared with human genome sequences. Mamm Genome, 2001, 12, 673-677.

15. Mittal, R.; Chhibber, S.; Sharma, S.; Harjai, K. Macrophage inflammatory protein-2, neutrophil recruitment and bacterial persistence in an experimental mouse model of urinary tract infection. Microbe Infect, 2004, 6, 1326-1332.

16. Harjai, K.; Mittal, R.; Chhibber, S.; Sharma, S. Contribution of Tamm-Horsfall protein to virulence of Pseudomonas aeruginosa in urinary tract infection. Microbe Infect, 2005, 7, 132-137.

17. Ladd, T.I.; Schmiel, D.; Nickel, J.C. The use of a radiorespirometric assay for testing the antibiotic sensitivity of catheter associated bacteria. J Urol, 1987, 138, 1451-1456.

18. Gupta, R.; Ganguly, N.K.; Ahuja, V.; Joshi, 
K.; Sharma, S. An ascending non-obstructive model for chronic pyelonephritis in BALB/c mice. J Med Microbiol, 1995, 43, 33-36.

19. Wills, E.D. Mechanism of lipid peroxide formation in animal tissues. Biochem J, 1965, 99, 667-676.

20. Ikeno, T.; Fukuda, K.; Ogawa, M.; Honda, M.; Tanabe, T.; Taniguchi, H. Small and rough colony Pseudomonas aeruginosa with elevated biofilm formation ability isolated in hospitalized patients. Microbiol Immunol, 2007, 51, 29-38.

21. Donlan, R.M. Biofilm formation: A clinically relevant microbiological process. Clin Infect Dis, 2001, 33, 1387-1392.

22. Jesaitis, A.J.; Franklin, M.J.; Berglund, D.; Sasaki, M.; Lord, C.I.; Bleazard, J.B.; Duffy, J.E.; Beyenal, H.; Lewandowski, Z. Compromised host defense on Pseudomonas aeruginosa biofilms: characterization of neutrophil and biofilm interactions. $J$ Immunol, 2003, 171, 4329-4339.

23. Schaeffer, A.J.; Schwan, W.R.; Hultgren, S.J.; Duncan, J.L. Relationship of type-1 pilus expression in Escherchia coli to ascending urinary tract infection in mice. Infect Immun, 1987, 55, 373-380.

24. Chen, C.P.; Song, S.C.; Gilboa-Garber, N.; Chang, K.S.S.; Wu, A.M. Studies on the binding sites of the galactose specific agglutin PA-IL from Pseudomonas aeruginosa. Glycobiol, 1998, 8, 7-16.

25. Angell, M.E.; Rehman, A.S.; Robbins, S.L. Active chronic pyelonephritis without evidence of bacterial infection. $N$ Engl J Med, 1968, 278, 1303-1308.

26. Kaisiske, B.L.; O'Donell, M.P.; Cleary, M.P.; Keane, W.F. Effect of reduced renal mass on tissue lipids and renal injury in hyperlipidemic rats. Kid Int, 1989, 35, 40-57.

27. Walker, T.S.; Tomlin, K.L.; Worthen, G.S.; Poch, K.R.; Lieber, J.G.; Saavedra, M.T.; Fessler, M.B.; Malcolm, K.C.; Vasil, M.L.; Nick, J.A. Enhanced Pseudomonas aeruginosa biofilm development mediated by human neutrophils. Infect Immun, 2005, 73, 36933701.

28. Guze, L.B.; Montgomerie, J.G.; Potter, C.S.; Kalmanson, G.M. Pyelonephritis XVI:
Correlation of parasite virulence in acute ascending Escherichia coli pyelonephritis in mice undergoing dieresis. Yale J Bio Med, 1973, 46, 203-211.

29. Kronborg, G.; Hanser, M.; Svenson, M.; Fomsguard, A.; Hoiby, N.; Bendtzen, K. Cytokines in sputum and serum from patients with cystic fibrosis and chronic Pseudomonas aeruginosa infection as markers of destructive inflammation in the lungs. Pediatr Pulmonol, 1993,15, 292-297.

30. Yadav, V.; Harjai, K.; Kaur, R.; Joshi, K.; Sharma, S. Urovirulence of Pseudomonas aeruginosa: planktonic cells vs. biofilm cells. Folia Microbiol, 2004, 49, 465-470.

31. Leid, J.G.; Willson, C.J.; Shirtliff, M.E.; Hassett, D.J.; Parsek, M.R.; Jeffers, A.K. The exopolysaccharide alginate protects Pseudomonas aeruginosa biofilm bacteria from IFN-gamma-mediated macrophage killing. J Immunol, 2005, 175, 7512-7518.

32. Costerton, J.W.; Stewart, P.S.; Greenberg, E.P. Bacterial biofilms: a common cause of persistent infections. Science, 1999, 284, 1318-1322.

33. Donlan, R.M.; Costerton, J.W. Biofilms: survival mechanisms of clinically relevant microorganisms. Clin Microbiol Rev, 2002, 15, 167-193.

34. O'Toole, G.; Kaplan, H.B.; Kolter, R. Biofilm formation as microbial development. Ann Rev Microbiol, 2000, 54, 49-79.

35. Hoiby, N.; Krogh Johansen, H.; Moser, C.; Song, Z.; Ciofu, O.; Kharazmi, A. Pseudomonas aeruginosa and the in vitro and in vivo biofilm mode of growth. Microbes Infect, 2001, 3, 23-35.

36. Brown, S.M.; Howell, M.L.; Vasil, M.L.; Anderson, A.J.; Hassett, D.J. Cloning and characterization of the katB gene of Pseudomonas aeruginosa encoding a hydrogen peroxide-inducible catalase: purification of KatB, cellular localization, and demonstration that it is essential for optimal resistance to hydrogen peroxide. J Bacteriol, 1995, 177, 6536-6544.

37. Hassett, D.J.; Schweizer, H.P.; Ohman, D.E. Pseudomonas aeruginosa sodA and sodB mutants defective in manganese- and iron- 
cofactored superoxide dismutase activity demonstrate the importance of the ironcofactored form in aerobic metabolism. $J$ Bacteriol, 1995, 177, 6330-6337.

38. Lu, X.; Roe, F.; Jesaitis, A.; Lewandowski, Z. Resistance of biofilms to the catalase inhibitor 3-amino-1,2, 4-triazole. Biotechnol Bioeng,
1998, 59, 156-162.

39. Alonso, A.; Rojo, F.; Martinze, J.L. Environmental and clinical isolates of Pseudomonas aeruginosa show pathogenic and biodegradative properties irrespective of their origin. Environ Microbiol, 1999, 1, 421427. 